\title{
Mitochondrial DNA variation reveals the presence of two management units in the sábalo Prochilodus lineatus (Characiformes: Prochilodontidae) from La Plata River basin
}

\author{
Alejandro Márquez ${ }^{1,2}$, Sofía Stareczek, ${ }^{2}$ María Noel Caraccio ${ }^{2}$, Inés Carrera ${ }^{2}$ \\ Eugenia Errico $^{2} \&$ Alfredo Nicolás Pereira ${ }^{2}$ \\ ${ }^{1}$ Facultad de Ciencias, Universidad de la República, Montevideo, Uruguay \\ ${ }^{2}$ Laboratorio de Bioquímica de Organismos Acuáticos, DINARA-MGAP, Montevideo, Uruguay \\ Corresponding author: Alejandro Márquez (ale@ fcien.edu.uy)
}

\begin{abstract}
The La Plata River basin, the second largest drainage basin in South America, supports important fisheries, in which the sábalo Prochilodus lineatus is the leading species measured as extracted volumes. To characterize the population structure of the sábalo in the middle and lower regions of the La Plata River basin, cytochrome b DNA sequences of 121 samples collected in La Plata, Paraná and Uruguay rivers were used. Results suggest the presence of at least two populations: one that we called "southern population" uses the La Plata River and the lower sections of the Paraná and Uruguay rivers and another population (called here "northern population") in the middle section of the Uruguay and Paraná rivers. The southern population would have a larger effective population size and coalescence-based analyses reveal an asymmetric gene flow, mainly from north to south. A striking result is that samples from the middle sections of the Paraná and Uruguay rivers are more alike to each other than they are to the other samples of their respective rivers. This similarity could be explained by historical reasons, probably as a consequence of the proximity that both rivers had until 100,000 years ago. The presence of different management units being exploited by the continental fisheries of three countries demands coordination at a regional level in order to maintain a sustainable fishery.
\end{abstract}

Keywords: Prochilodus lineatus; continental fisheries; population genetics; stock discrimination; Uruguay River; Paraná River

\section{INTRODUCTION}

The La Plata River basin is the second largest in South America, covering approximately 3 million square kilometers and comprising major rivers such as Paraguay, Paraná, Uruguay and La Plata (Fig. 1). These rivers show great species richness, including several migratory species such as the sábalo, Prochilodus lineatus. It is a bottom-feeding species that perform migratory movements that respond mainly to breeding and feeding (Sverlij et al., 1993). Two species of Prochilodus, P. lineatus and P. scrofa have been described (Sverlij et al., 1998) for the lower and middle regions of the La Plata River basin. However, phylogeographic studies across the basin have not found evidence of the presence of more than one species (Sivasundar et al., 2001), maintaining P. lineatus as the only valid species in this basin.

The basin's fish resources, particularly the migratory ones, are a very important source of protein to the river dwellers and support important artisanal fisheries, being a work opportunity to a large number of families. The sábalo is the most abundant commercial freshwater resource in the basin, especially in Argentina, Uruguay and Brazil. The volume extracted is mainly exported, although a fraction is sold in the domestic market, mainly in Argentina and Brazil. This species is also considered useful for aquaculture purposes, being introduced on Asian's farms outside its original continent (Kalous et al., 2012). 


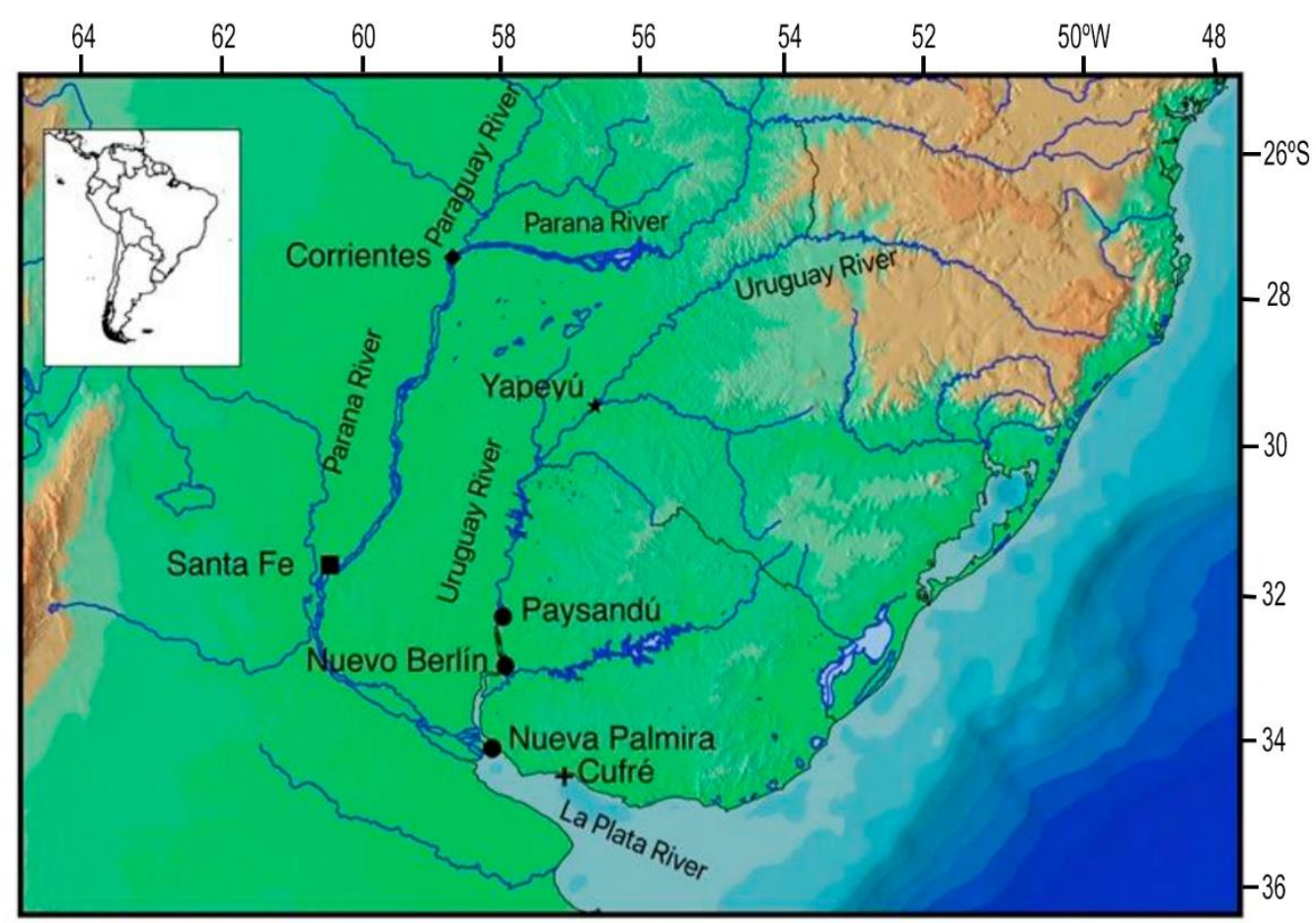

Figure 1. Localities from the lower La Plata River Basin from where samples of Prochilodus lineatus were collected. Symbols represent a sector of the rivers: $\square$ Lower Parana River, $\bullet$ Middle Parana River, $\bullet$ Lower Uruguay River, $\star$ Middle Uruguay River, + La Plata River.

Fisheries management requires an understanding of biological principles (Allendorf et al., 1987). Knowledge about the population structure of a fishery species is of outstanding importance given that different populations should be exploited separately for their conservation. Fish species are often composed of discrete stocks, and these stocks may react to harvesting more or less independently (Carvalho \& Hauser, 1994). The concept of stock in fisheries has evolved across time from a simple operational definition to describe the individuals that are being exploited (Waldman, 2005) to "genetics stocks" defined as a reproductively isolated unit, which is genetically different from other stocks (Jamieson, 1973; Ovenden, 1990; Carvalho \& Hauser, 1994), and integrated by randomly mating individuals (Ihssen et al., 1981) that conforms a population that share a shared gene pool (Larkin, 1992). About implications for conservation, the concept of "management units" was also proposed in order to consider units which show incomplete phylogenetic sorting of mtDNA allele as a concept specially applied to conservation (Moritz, 1994; Fraser \& Bernatchez, 2001).

Genetic and morphometric studies of $P$. lineatus were done in the La Plata River basin but restricted to the upper section of the Paraná River, failing to detect population structure (Revaldaves et al., 1997; Machado \& Foresti, 2012; Ferreira et al., 2017). Also, one phylogenetic study involving a broad sample distribution suggested high levels of gene flow across the entire basin (Sivasundar et al., 2001). However, Rueda et al. (2013) detected seasonal genetic variation in a section of the lower Uruguay River, suggesting the presence of mixed stock.

The fundamental aim of this study was to characterize the genetic variability and population structure of sábalo in different locations in the lower and middle La Plata basin, including the Uruguay, Paraná and La Plata rivers, through the analysis of mitochondrial DNA sequences.

\section{MATERIALS AND METHODS}

Samples of muscle tissue were collected from the La Plata River (Cufré, $\mathrm{n}=14$ ), lower Uruguay River (Nueva Palmira, $\mathrm{n}=16$; Nuevo Berlin, $\mathrm{n}=14$; Paysandú, $\mathrm{n}=30$ ), middle Uruguay River (Yapeyú, $\mathrm{n}=$ 24), lower section of Paraná River (Santa Fe, $n=10$ ) and from the middle section of Paraná River (Corrientes-Posadas, $n=13$ ) (Fig. 1). Samples were preserved in $96 \%$ ethanol at room temperature until DNA extraction using a salting out protocol (Miller et 
al., 1988). A fragment of $738 \mathrm{pb}$ of the mitochondrial cytochrome $\mathrm{b}$ was amplified by polymerase chain reaction (PCR) using primers MVZ16 (Moritz et al., 1992) and L14735 (Bartlett \& Davidson, 1991).

Amplification was conducted under the following conditions: an initial denaturation step at $94^{\circ} \mathrm{C}(2 \mathrm{~min})$, 35 cycles of $94^{\circ} \mathrm{C}(1 \mathrm{~min}), 50^{\circ} \mathrm{C}(1 \mathrm{~min})$ and $72^{\circ} \mathrm{C}(1$ min) and a final extension step at $72^{\circ} \mathrm{C}(5 \mathrm{~min})$. PCR products were sequenced directly with the same primers used in the amplification, and sequences were edited and aligned with Bioedit (Hall, 1999).

\section{Population structure}

The genetic diversity was measured as: haplotype diversity $(H)$, the probability of taking two individuals with different sequences; nucleotide diversity $(\pi)$, the probability that two randomly chosen homologous sites are different. Population structure of the samples was assessed using $\mathrm{F}_{\mathrm{ST}}$, and Analysis of Molecular Variance (AMOVA). Values of diversity and the genetic structure analyses were calculated using Arlequin software, version 3.5 (Excoffier \& Lischer, 2010).

Spatial clustering of individuals was inferred using a Bayesian estimation applied in program Geneland (Guillot et al., 2005), with ten runs of 100,000 MCMC iterations with a thinning interval of 100 , where $\mathrm{K}$ was allowed to vary between 1 and 4 . A coalescence-based method was used to compare alternative migration patterns between populations as implemented in the software Migrate-n version 3.6.11. The Bayesian search strategy was conducted using the following parameters: an MCMC search of 500,000 burn-in steps with parameters recorded every 100 steps. The prior distribution for the parameters was uniform, with boundaries defined after explorative runs, $\Theta$ (mutationscaled population size) (min: 0.0, max: 2.0, delta: 0.2) and migration (min: 0.0, max: 10 000, delta: 1,000). A static heating scheme with four different temperatures $(1.0,1.5,3.0$, and 10,000) was employed, where acceptance-rejection swaps were proposed at every step. The model comparison was made using logequivalent Bayes factors (LBF) that need the calculation of marginal likelihoods. Bidirectional immigration rates and effective population size are measured as $M$ (mutation-scaled immigrant's rates) and $\Theta$ according to the model chosen. If $\Theta$ and $M$ are multiplied together, the number of immigrants per generation $x \mathrm{Nm}$ can be calculated. A median-joining network of haplotypes (Bandelt et al., 1999) was constructed using PopART (Leigh \& Bryant, 2015) to infer relationships between sequences.

\section{RESULTS}

Fifty haplotypes were identified in 121 individuals (Genebank accession numbers: KY126481-KY126614). Genetic diversity was relatively high in all localities (Table 1).

Pairwise $F_{S T}$ revealed that the sampled localities could be grouped into two distinct populations. One formed by samples collected from the La Plata River with the lower sections of the Paraná and Uruguay rivers (Table 2) and the second by samples collected from middle Uruguay River and middle Paraná River regions. These were named northern and southern populations, respectively. Although only 10 individuals were sampled form Santa Fe (middle section of the Paraná River), the pairwise F $_{\text {ST }}$ were 0 (negative values should be considered 0 ) and not significant, which supports the conclusion that the middle section of the Paraná River is closely related to the other localities of the southern population.

In AMOVA, four hypotheses were tested: one based on $\mathrm{F}_{\mathrm{ST}}$ results and three according to a geographical criterion (see text in Table 3). The grouping of samples with the highest percentage of variance explained by differences among groups was that proposed by the pairwise $F_{S T}$ comparisons (Table 3), that is grouping localities in two populations, one occupying the southern region of the basin and another with the samples from the middle portions of Uruguay and Paraná rivers. This means that the sábalos of the Paraná and Uruguay rivers from their middle sections were genetically more similar to each other than they were to the lower regions of their respective rivers. Negative variance components can occur in the absence of genetic structure because the true value of the parameter to be estimated is zero.

Haplotypic diversity was similar considering this scenario of two populations, but sequences were less diverse in the northern population as was measured by the nucleotide diversity (Table 1).

Bayesian clustering method implemented in Geneland software indicated that individuals could be assigned to two populations. The probability maps for the distribution of these two population clusters partitioned the range of Prochilodus lineatus into a northern population (middle portions of Paraná and Uruguay rivers), and a southern population (composed by samples from inferior portions of Paraná, Uruguay and La Plata rivers) (Fig. 2).

As a consequence, it was assumed the existence of two populations and coalescence-based analyses was developed considering a southern population, compo- 
Table 1. Population diversity indices of Prochilodus lineatus. Number of samples (n), number of haplotypes (H), number of polymorphic sites $(\mathrm{S})$, haplotype $(h)$ and nucleotide diversity $(\pi)$. Northern region is the result of grouping together localities of middle sectors of Paraná and Uruguay rivers (as suggested by results), while southern region grouped the remaining samples.

\begin{tabular}{llccccc}
\hline \multirow{2}{*}{ Region } & \multirow{2}{*}{ Sample } & \multicolumn{5}{c}{ Population diversity indices } \\
\cline { 3 - 7 } & & $\mathrm{n}$ & $\mathrm{H}$ & $\mathrm{S}$ & $h$ & $\pi \times 100$ \\
\hline De la Plata River & Cufré & 14 & 10 & 21 & 0.923 & 0.795 \\
& Nueva Palmira & 16 & 14 & 23 & 0.975 & 0.790 \\
Lower Uruguay River & Nuevo Berlín & 14 & 8 & 17 & 0.769 & 0.649 \\
& Paysandú & 30 & 19 & 32 & 0.920 & 0.753 \\
Middle Uruguay River & Yapeyú & 24 & 14 & 20 & 0.859 & 0.510 \\
Lower Paraná River & Santa Fe & 10 & 6 & 16 & 0.844 & 0.774 \\
Middle Paraná River & Corrientes & 13 & 9 & 14 & 0.910 & 0.462 \\
Southern & & 84 & 41 & 51 & 0.898 & 0.752 \\
Northern & & 37 & 19 & 24 & 0.872 & 0.489 \\
\hline
\end{tabular}

Table 2. Lower La Plata basin pairwise $\mathrm{F}_{\mathrm{ST}}$ between sampled localities of Prochilodus lineatus. Numbers in bold represent significant $\mathrm{F}_{\mathrm{ST}}$ values between sample pairs. Negative values should be considered as zero, indicating no genetic subdivision between samples as well as non-significant values.

\begin{tabular}{lcccccc}
\hline Sample & Cufré & Nueva Palmira & Nuevo Berlin & Paysandú & Yapeyú & Santa Fe \\
\hline Cufré & - & & & & & \\
Nueva Palmira & -0.031 & - & & & & \\
Nuevo Berlin & 0.035 & -0.004 & - & & & \\
Paysandú & -0.034 & -0.018 & 0.047 & - & & \\
Yapeyú & $\mathbf{0 . 1 1 7}$ & $\mathbf{0 . 2 1 6}$ & $\mathbf{0 . 3 3 4}$ & $\mathbf{0 . 1 2 3}$ & - & \\
Santa Fe & -0.053 & -0.060 & -0.010 & -0.034 & $\mathbf{0 . 1 9 6}$ & - \\
Corrientes & $\mathbf{0 . 1 0 9}$ & $\mathbf{0 . 2 1 3}$ & $\mathbf{0 . 3 4 3}$ & $\mathbf{0 . 1 1 9}$ & -0.037 & $\mathbf{0 . 1 9 9}$ \\
\hline
\end{tabular}

sed by the La Plata River and the lower sections of the Uruguay and Paraná rivers; and a northern population consisting of the middle sections of the Uruguay and Paraná rivers.

Coalescent analyses for migration model comparisons implemented in Migrate-n, highly supported ( $P$ $<0.99$ ) the full model of migration (i.e., two population sizes and two migration rates) with a $\Theta$ higher in the southern population $(\Theta=0.278)$ than in the northern population $(\Theta=0.009)$. This model states a bidirectional gene flow between region, but the migration rate was higher from the north to the south $\left(x \mathrm{Nm}_{\mathrm{North}} \rightarrow\right.$ South $=736.7, x \mathrm{Nm}_{\text {South } \rightarrow \text { North }}=0.03$ immigrants per generations) (Fig. 3).

The haplotype network shows several regions with star-like topologies and can be seen that considering the two most represented haplotypes, one (Hap 2 in bold) is mainly represented in the southern population (red), and the other (Hap 18 in bold) is mainly found in the northern population (yellow) (Fig. 4). However, no reciprocal monophyly was observed, showing that the population differences were observed mainly in the relative frequencies of the variants (Kizirian \& Donnelly, 2004).

\section{DISCUSSION}

Knowledge of the population genetic structure in a fishery is essential for a rational design of their exploitation to avoid population losses. Population genetic analysis indicates the presence of at least two populations of the sábalo, Prochilodus lineatus, in the lower and middle basin of the La Plata River that should be considered as different "genetic stocks." One population covers the lower section of the basin, whereas at least another population occurs in the middle sections of the Uruguay and Paraná rivers. The presence of more than one population in the Uruguay River was also suggested by Rueda et al. (2013), who detected a seasonal variation in this species in the lower section of the Uruguay River using microsatellites, proposing a differential use of the area by different populations along the year.

A striking result is that samples from the middle sections of the Paraná and Uruguay rivers are more alike to each other than they are to the other samples of their respective rivers. This similarity of the sábalo from the middle section of Paraná and Uruguay rivers can be explained in two ways: they are currently geogra- 
Table 3. Analysis of molecular variance (AMOVA) tests of Prochilodus lineatus evaluating groupings based on geographical criterions (hypothesis 1, 3 and 4 ) and the one suggested by the $\mathrm{F}_{\mathrm{ST}}$ results (hypothesis 2). In bold, the grouping of localities with the best percentage of explained molecular variance due to differentiation among groups. 1) Four groups, assembling samples by the river; 2) suggested by $\mathrm{F}_{\mathrm{ST}}$, that is, two groups, one southern group composed by samples collected from lower Uruguay River, De La Plata River and Lower Paraná River, one northern group composed by localities collected from middle Uruguay River and middle Paraná River. Hypothesis 3 and 4 are variants of that suggested by F $_{\text {ST }}$ results; 3 ) in the northern group Yapeyú and Corrientes were separated; 4) the southern group separated into two groups.

\begin{tabular}{lccc}
\hline \multirow{2}{*}{ Hypothesis (groupings) } & \multicolumn{3}{c}{ Percentage of the explained molecular variance } \\
\cline { 2 - 4 } & Among groups & $\begin{array}{c}\text { Among populations } \\
\text { within groups }\end{array}$ & Within-population \\
\hline 1) Localities by river & -0.60 & 5.12 & 95.48 \\
2) Suggested by F & $\mathbf{1 8 . 5 7}$ & $\mathbf{- 1 . 1 0}$ & $\mathbf{8 2 . 5 3}$ \\
3) Yapeyu $\neq$ Posadas & 16.12 & -0.50 & 84.37 \\
4) Cufré + Santa Fe $\neq$ Lower Uruguay River & 13.07 & -0.86 & 87.79 \\
\hline
\end{tabular}
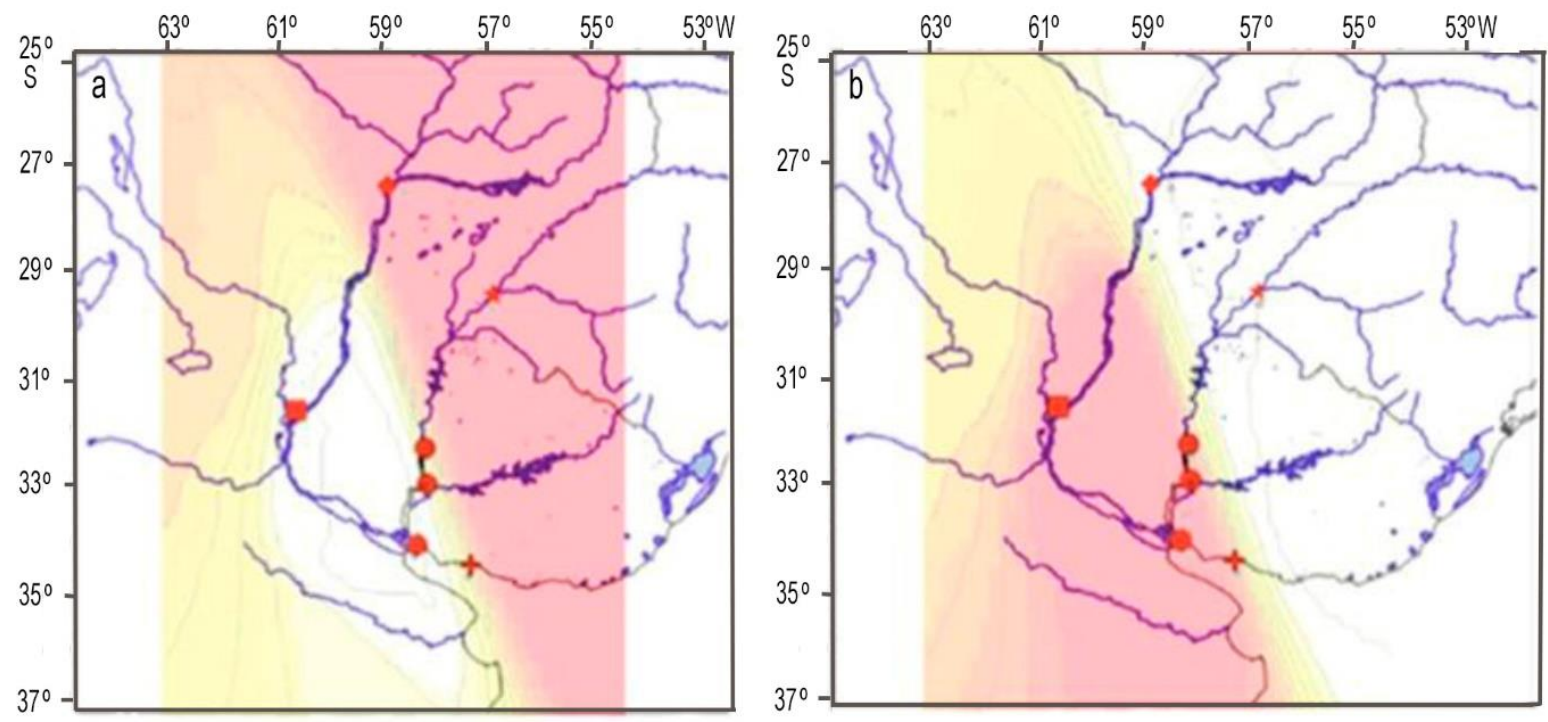

Figure 2. Posterior probability maps for each cluster in the Bayesian analyses of Geneland software of Prochilodus lineatus. The colored contours show regions of high (light yellow) to the low (red) posterior probability of membership to cluster 1 a) or southern population, and cluster $2 \mathrm{~b}$ ) or northern population. Symbols for localities are as in figure 1; circles, crosses and squares belong to the southern population, whereas locations represented with stars and diamonds belong to the northern population.

geographically connected, or they were connected at some point of their histories. The first explanation could be supported by the fact that between the Uruguay and Paraná rivers there is a wetland called "Esteros del Iberá," from where streams drain to the two rivers. The Aguapey River, which flows into the Uruguay River, passes just $8 \mathrm{~km}$ from the Paraná River in part of its route. If this wetland represents a zone of nursery for this species, periods of high flooding could allow individuals to be exchanged between the middle sectors of the Paraná and Uruguay rivers.

The second explanation implies contact in some historical period but not necessary at present. The connection between the middle sections of the rivers occurred until 100 or 150 thousand years ago, when the main channel of the Paraná River was close to the Uruguay River. The Tapebicuá formation was indeed the consequence of this ancient riverbed of the Paraná River when it was connected with the Uruguay River (Iriondo \& Krohling, 2008). The "Esteros del Iberá" is the result of the old path of the Paraná River. It is also plausible that the similarity between the sábalos of both rivers is the result of historical and present biological process.

There is a possibility, given that the cytochrome $b$ is a relatively conserved marker, that detection of popu- 


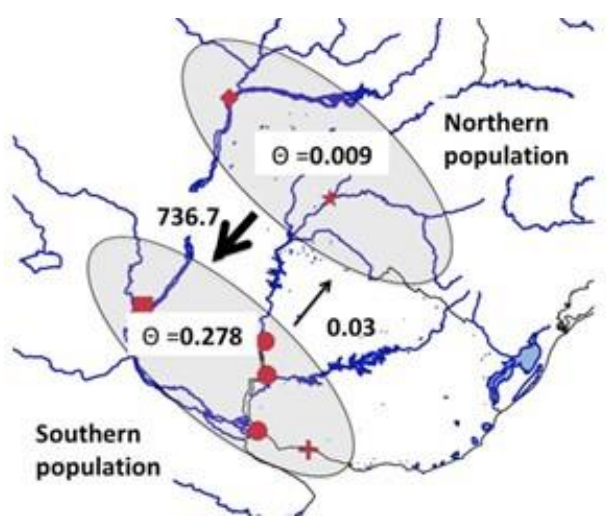

Figure 3. Southern and northern populations' scheme describing Prochilodus lineatus best migration model, as inferred by Migrate-n software. The numbers next to the arrows are the effective number of migrants per generation $(\mathrm{xNm})$ estimated for the most probable model, and the numbers within the grey forms are the mutation-scales population sizes for the different populations.

lation differences between the two middle sections of the Uruguay and Paraná rivers failed, if they were produced in the last 100.000 years. Therefore, the hypothesis that the middle sectors of both rivers could sustain distinct populations cannot be discarded entirely. On the other hand, as adifferentiation between northern and southern populations wasrevealed, the differences between the described populations need to be ancient enough to be detected with cytochrome $b$.

The lower section of the Uruguay River has an additional complication. Due to the possibility that eggs and larvae can drift from the middle to the lower section of the river through the Salto Grande Dam (Fuentes et $a l ., 2016)$ and the unfeasibility for these individuals to come back as adults (Quirós, 1988), the stock mixture detected by Rueda et al. (2013) in the lower section of the Uruguay River can be explained. The estimates of gene flow with Migrate-n reinforce the observation that the passage of individual between sections of the river is asymmetrical and supports the hypothesis of a unidirectional flow of individuals downstream from the middle to the lower section.

The sábalo possess high levels of genetic variation, which is consistent with species maintaining a high population size (Hague \& Routman, 2016). This species is the main fishing resource due to its abundance in the big rivers of the basin, mainly in the lower sections of the Uruguay and Paraná rivers (Iwaszkiw \& Lacoste, 2011). Given that the southern population is widely distributed in extensive areas of the rivers whereas the northern population is restricted to segments where the river flow is lower, the effective population sizes estimated by Migrate-n agree with the actual relative population sizes of both populations.

\section{Consequences for the fishery management}

The presence of two populations (usually called stocks by fisheries administrators) implies that management decisions need to be independent in the two units. There are more than one definitions of stock, varying from considering that a stock comprises the fishes exploited in a specific geographical area (they are called "fishery stock" or "harvested stock"), to "genetic stocks" defined as reproductively isolated units (Jamieson, 1973; Ovenden, 1990; Smith et al., 1990; Carvalho \& Hauser, 1994; Hauser \& Ward, 1998), or "management units" ((Moritz, 1994; Fraser \& Bernatchez, 2001). In those cases where population differences were genetically detected (as was in the case of sábalo), the practical "harvested stock" units used mainly in the management, can be supported by the identification of reproductively isolated units. In this way, exploitation of a natural resource can be made avoiding loss of biodiversity distribution, taking into account the genetic composition of populations and the implications that this loss implies for the functioning of ecosystems and the provision of ecosystem services (Luck et al., 2003).

In the case of the sábalo, the most intensive fisheries occur in the lower sections of the Paraná, La Plata and Uruguay rivers. The management of the species as a whole has the complexity of being exploited by three countries (Argentina, Uruguay and Brazil) that has almost no coordination among them, with the only exception of the shared section of the Uruguay River, between Argentina and Uruguay (at the Comision Administradora del Río Uruguay jurisdiction). Furthermore, the possibility of a mixture of stocks in some sections of the lower basin adds additional complexity to administrative decisions.

In the Paraná River, the statistics of the fishing resources should take into account the identification of two management units, one in the northern part and one in the south, the last shared with the La Plata River and lower Uruguay River. The same attention must be taken for the management of the sábalo in the Uruguay River, where different stocks are present in the lower and middle sections, so they should be managed as different units.

The management of both middle sections of Paraná and Uruguay rivers as a unique stock can be controversial because the genetic marker utilized in this study does not exclude the possibility that the lack of differences may be due to historical processes and therefore sábalos from both regions could be currently genetically isolated. The use of hypervariable markers may help in the explanation about the origin of this similarity, valuing the contribution of the historical and modern process. 


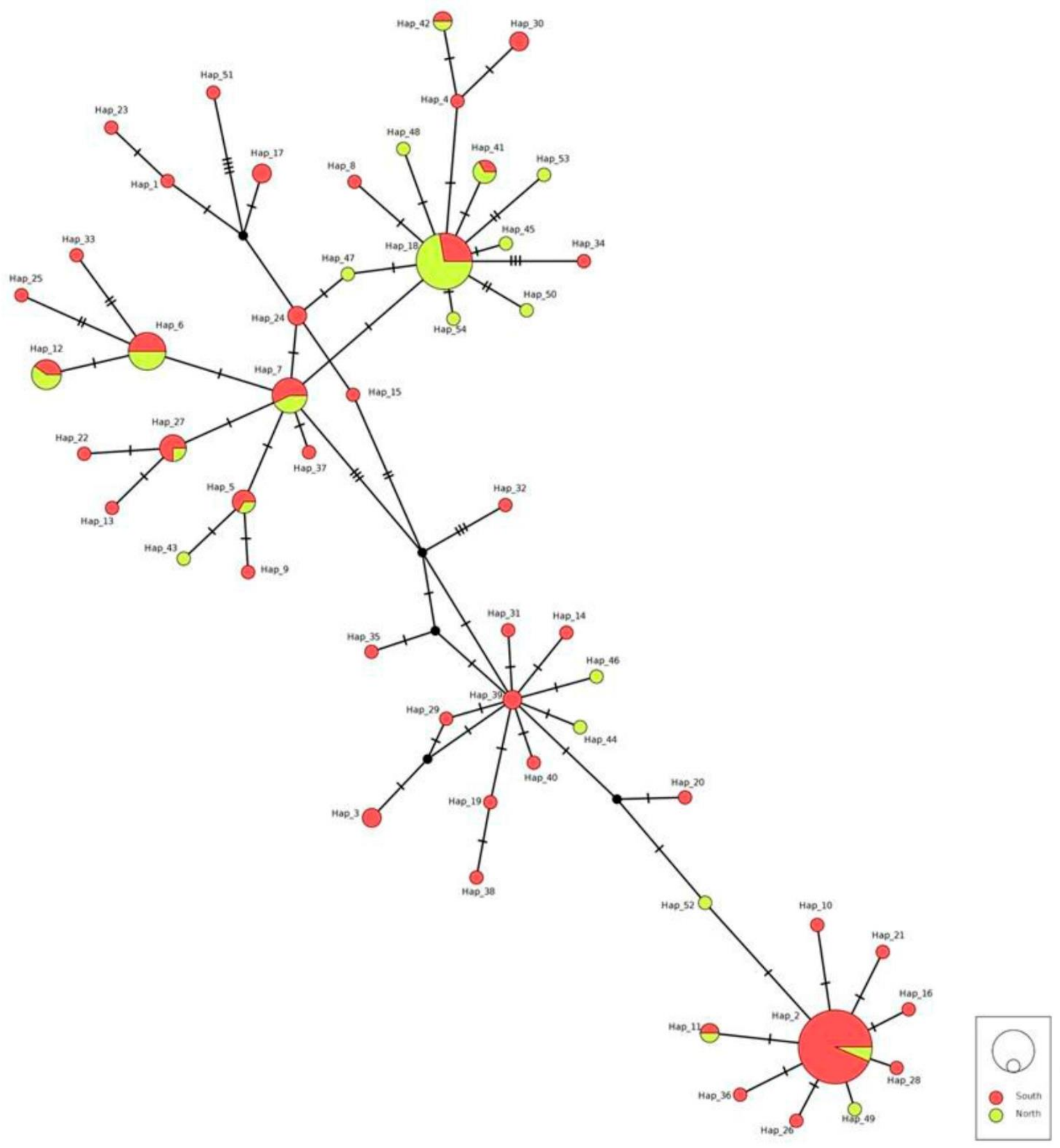

Figure 4. Haplotype network of sequences of cytochrome b of Prochilodus lineatus. The diameter of the circle is proportional to the frequency of the haplotype in the northern (yellow) and southern (red) population. Dashes in the connections between haplotypes represent mutational steps. In the small box below on the right, the smaller open circle represents 1 sample and the larger circle represents 10 samples.

\section{ACKNOWLEDGMENTS}

This study is a result of activities in the "Programa de Conservación de la Fauna Íctica y Los Recursos Pesqueros del Río Uruguay" of the "Comisión Admi- nistradora del Río Uruguay" (CARU). We sincerely appreciate the financial support of CARU for the study and the contribution of the employees of CARU and fishers. 


\section{REFERENCES}

Allendorf, F.W., Ryman, N., \& Utter, F.M. 1987. Genetics and fishery management. Past, present, and future. In: Ryman, N. \& Utter, F.M. (Eds.). Population genetics $\&$ fishery management. The Blackburn Press, Seattle.

Bandelt, H.J., Forster, P. \& Rohl, A. 1999. Median-joining networks for inferring intraspecific phylogenies. Molecular Biology and Evolution, 16(1): 37-48.

Bartlett, S.E. \& Davidson, W.S. 1991. Identification of Thunnus tuna species by the polymerase chain reaction and direct sequence analysis of their mitochondrial cytochrome $b$ genes. Canadian Journal of Fisheries and Aquatic Sciences, 48(2): 309-317.

Carvalho, G.R. \& Hauser, L. 1994. Molecular genetics and the stock concept in fisheries. Reviews in Fish Biology and Fisheries, 4(3): 326-350.

Excoffier, L. \& Lischer, H.E.L. 2010. Arlequin suite ver 3.5: a new series of programs to perform population genetics analyses under Linux and Windows. Molecular Ecology Resources, 10(3): 564-567.

Ferreira, D.G., Souza-Shibatta, L., Shibatta, O.A., Sofia, S.H., Carlsson, J., Dias, J.H.P., Makrakis, S. \& Makrakis, M.C. 2017. Genetic structure and diversity of migratory freshwater fish in a fragmented Neotropical river system. Reviews in Fish Biology and Fisheries, 27(1): 209-231.

Fraser, D.J. \& Bernatchez, L. 2001. Adaptive evolutionary conservation: towards a unified concept for defining conservation units. Molecular Ecology, 10(12): 27412752.

Fuentes, C.M., Gómez, M.I., Brown, D.R., Arcelus, A. \& Espinach, A. 2016. Downstream passage of fish larvae at the Salto Grande Dam on the Uruguay River. River Research and Applications, 32(9): 1879-1889.

Guillot, G., Mortier, F. \& Estoup, A. 2005. GENELAND: a computer package for landscape genetics. Molecular Ecology Notes, 5(3): 712-715.

Hague, M.T.J. \& Routman, E.J. 2016. Does population size affect genetic diversity? A test with sympatric lizard species. Heredity, 116(1): 92-98.

Hall, T. 1999. BioEdit: a user-friendly biological sequence alignment editor and analysis program for Windows 95/ 98/NT. Nucleic Acids Symposium Series, 41: 9598.

Hauser, L. \& Ward, R.D. 1998. Population identification in pelagic fish: the limits of molecular markers. In: Carvalho, G.R. (Ed.). Advances in Molecular Ecology. IOS Press, Amsterdam, pp. 191-224.

Ihssen, P.E., Booke, H.E., Casselman, J.M., McGlade, J.M., Payne, N.R. \& Utter, F.M. 1981. Stock identification: materials and methods. Canadian Journal of Fisheries and Aquatic Sciences, 38(12): 1838-1855.
Iriondo, M.H. \& Krohling, D.M. 2008. Cambios ambientales en la cuenca del río Uruguay. Desde dos millones de años hasta el Presente. Colección Ciencia y Técnica. Universidad Nacional del Litoral, Santa Fe.

Iwaszkiw, J.M. \& Lacoste, F.F. 2011. La pesca artesanal en la Cuenca del Plata (Argentina) y sus implicancias en la conservación de la biodiversidad. Revista del Museo Argentino de Ciencias Naturales, 13: 21-25.

Jamieson, A. 1973. Genetic "tags" for marine fish stocks. In: Hardin, J.F.R. (Ed.). Sea Fisheries Research. Elek Science, London, pp. 91-99.

Kalous, L., Bui, A.T., Petrtýl, M., Bohlen, J. \& Chaloupková, P. 2012. The South American freshwater fish Prochilodus lineatus (Actinopterygii: Characiformes: Prochilodontidae): new species in Vietnamese aquaculture. Aquaculture Research, 43(6): 955-958.

Kizirian, D. \& Donnelly, M.A. 2004. The criterion of reciprocal monophyly and classification of nested diversity at the species level. Molecular Phylogenetics and Evolution, 32(3): 1072-1076.

Larkin, P.A. 1992. The stock concept and management of Pacific salmon. In: Simon, R.C. \& Larkin, P.A. (Eds.). The stock concept in Pacific salmon. University of British Columbia, Vancouver, pp. 11-15.

Leigh, J.W. \& Bryant, D. 2015. POPART: full-feature software for haplotype network construction. Methods in Ecology and Evolution, 6(9): 1110-1116.

Luck, G.W., Daily, G.C. \& Ehrlich, P.R. 2003. Population diversity and ecosystem services. Trends in Ecology \& Evolution, 18(7): 331-336.

Machado, M.R.F. \& Foresti, F. 2012. Morphometric characteristics of Prochilodus lineatus (Valenciennes 1847), of the migratory and resident stocks of the river Mogí-Guaçu, São Paulo State, Brazil. Acta Scientiarum. Animal Sciences, 34(4): 341-346.

Miller, S.A., Dykes, D.D. \& Polesky, H.F. 1988. A simple salting out procedure for extracting DNA from human nucleated cells. Nucleic Acids Research, 16(3): 1215.

Moritz, C. 1994. Defining 'Evolutionarily Significant Units' for conservation. Trends in Ecology \& Evolution, 9(10): 373-375.

Moritz, C., Schneider, C.J., Wake, D.B. \& Url, S. 1992. Evolutionary relationships within the Ensatina eschscholtzii complex confirm the ring species interpretation. Systematic Biology, 41(3): 273-291.

Ovenden, J. 1990. Mitochondrial DNA and marine stock assessment: a review. Marine and Freshwater Research, 41(6): 835-853.

Quirós, R. 1988. Estructuras para asistir a los peces no salmónidos en sus migraciones: América Latina. Food and Agriculture Organization, Rome.

Revaldaves, E., Renesto, E. \& Machado, M.F. 1997. Genetic variability of Prochilodus lineatus (Characi- 
formes, Prochilodontidae) in the upper Paraná River. Brazilian Journal of Genetics, 20(3): 381-388.

Rueda, E.C., Carriquiriborde, P., Monzón, A.M., Somoza, G.M. \& Ortí, G. 2013. Seasonal variation in genetic population structure of sábalo (Prochilodus lineatus) in the Lower Uruguay River. Genetica, 141(7-9): 401407.

Sivasundar, A., Bermingham, E. \& Ortí, G. 2001. Population structure and biogeography of migratory freshwater fishes (Prochilodus: Characiformes) in major South American rivers. Molecular Ecology, 10: 407-417.

Smith, P.J., Jamieson, A. \& Birley, A.J. 1990. Electrophoretic studies and the stock concept in marine teleosts. ICES Journal of Marine Science, 47(2): 231245.

Received: 20 December 2018; Accepted: 18 March 2019
Sverlij, S.B., Espinach Ros, A. \& Ortí, G. 1993. Synopsis de los datos biológicos del sábalo Prochilodus lineatus (Valenciennes, 1847). FAO Fisheries Synopsis. Food and Agriculture Organization, Rome.

Sverlij, S.B., Delfino Schenke, R.L., López, H.L. \& Espinach Ros, A. 1998. Peces del Río Uruguay. Guía ilustrada de las especies más comunes del Río Uruguay inferior y el embalse de Salto Grande. Comisión Administradora del Río Uruguay, Paysandu.

Waldman, J.R. 2005. Defining of stocks: an evolving concept. In: Cadrin X., Friedland, K.D. \& Waldman, J.R. (Eds.). Stock identification methods. Application in fishery science. Elsevier Academic Press, Cambridge, pp. 7-16. 